\title{
100th anniversary of the discovery of cosmic radiation: the role of Günther and Tegetmeyer in the development of the necessary instrumentation
}

\author{
R. G. A. Fricke ${ }^{1}$ and K. Schlegel ${ }^{2}$ \\ ${ }^{1}$ Behringstr. 30, 38300 Wolfenbüttel, Germany \\ ${ }^{2}$ Copernicus Gesellschaft e.V., Bahnhofsallee 1e, 37081 Göttingen, Germany \\ Correspondence to: K. Schlegel (kristian.schlegel@copernicus.org)
}

Received: 20 September 2012 - Accepted: 5 November 2012 - Published: 20 November 2012

\begin{abstract}
The year 2012 marks the 100th anniversary of the discovery of cosmic radiation by the Austrian physicist Victor Franz Hess (1883-1964), obtained onboard manned balloons, one of them launched up to an altitude of $5.3 \mathrm{~km}$. His discovery earned him the Nobel Prize in 1936. The discovery follows in the context of the investigation of atmospheric electricity and of the newly discovered radioactivity, in particular with respect to $\gamma$ rays. Starting from simple ionization chambers, the instruments were developed during an interplay between functional requirements, scientific progress and available manufacturing technologies.

The authors of this contribution take this anniversary as an opportunity to describe the instrumentation used by Hess, as well as further developments in the instrumentation which took place in the decades following Hess' discovery. This manuscript also discusses details of the company who manufactured Hess' instrument, "Günther \& Tegetmeyer" based in Braunschweig, Germany. This company did not only build instruments for Hess and the research on cosmic rays, but also for other scientific disciplines and for well-known researchers and discoverers.
\end{abstract}

\section{Introduction}

In the decades after the discovery of radioactivity by Henry Becqerel (1852-1908) in 1896, one focus of research was the ability of the radiation to ionize the air. Apart from the use of phosphorescent materials and photographic plates, radiation was mainly investigated by means of electrometers ${ }^{1}$. The German teachers Julius Elster (1854-1920) and Hans Geitel (1855-1923), for instance, put radioactive material together with a Luftelektrischer Zerstreuungsapparat (atmospheric electricity dissipation apparatus) under a glass vessel (Fig. 1). The radiation ionized the air in the vessel, increased in turn its conductivity and the resulting current reduced the

\footnotetext{
${ }^{1}$ Electroscopes had already been used since the middle of the 18th century and were continuously improved (Poggendorff, 1879); the well-known gold-leaf electroscope was introduced in 1787. In the following we use the term electrometer (Elektrometer in the original German scientific papers).
}

applied charge. Its values could be read from a scale with a microscope.

In 1901 scientists realized that the air in such a device became electrically conductive even when no radioactive material was present (Elster and Geitel, 1901; Wilson, 1901). This discovery was eventually interpreted as the consequence of an energetic $\gamma$ radiation penetrating the walls of the vessel. The source of this radiation, however, remained obscure; some scientists speculated about an extraterrestrial origin. As Wilson (1901) expressed, “...the continuous production of ions in dust-free air could be explained as being due to radiation from sources outside our atmosphere, possibly radiation like Röntgen rays or cathode rays, but of enormously greater penetrating power."

In the following we will briefly describe some first attempts to identify the source of this radiation (Sect. 2), then Hess' investigations and results (Sect. 3), followed by a brief account of the company Günther \& Tegetmeyer (G\&T in 


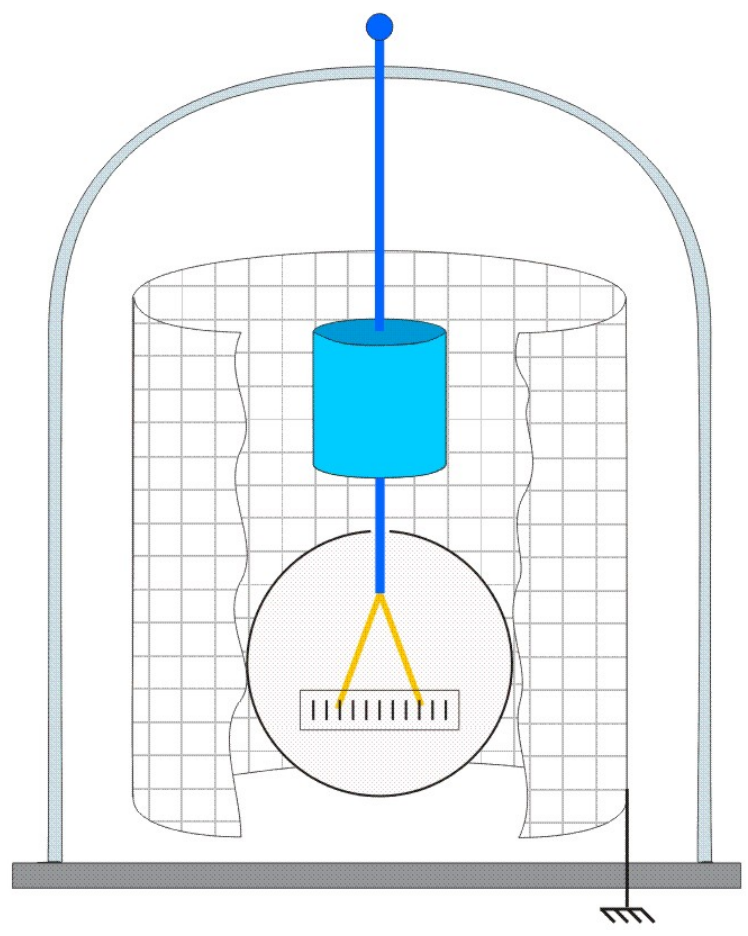

Figure 1. Schematic sketch of a bifilar (yellow) electrometer as used for radioactivity research. A radioactive sample was placed in the vessel (glass) and ionized the air therein. The electroscope was charged from outside, and the current flowing between the cylinder electrode (blue) and the surrounding wire mesh was derived from the charge decrease, read from the electroscope scale (adapted from the Glasglockenapparat of Geitel, 1900).

the following) in Sect. 4, and some details about other instruments built by this company for well-known customers (Sect. 5).

\section{First investigations of the penetrating radiation}

In order to clarify the source of the penetrating radiation, several experiments were performed towards the end of that decade. In the fall of 1908, the teacher Karl Bergwitz (18751958) started measurements from a balloon over Braunschweig, Germany. At an altitude of $1300 \mathrm{~m}$, however, he had to abandon the measurements because of a malfunctioning of his instrument (Bergwitz, 1910). More successfully, Albert Gockel (1860-1927) reached an altitude of $4500 \mathrm{~m}$ in 1909 (Gockel, 1910, 1911). The physicist and Jesuit Theodor Wulf (1868-1946) conducted measurements in Paris on the Eiffel tower in March/April 1910 on the height dependence of this radiation (Wulf, 1910). None of these experiments yielded a clarifying result.

Bergwitz, Gockel and Wulf used simple, closed cylinders with an inner rod as a detector. The ionization produced was measured with a bifilar electrometer, invented by Theodor Wulf (similar to that shown in Fig. 2). Wulf's improvement of existing electrometers was to use two thin metal filaments and to fix their lower end to an insulator with the help of quartz strings. This rendered the instrument insensitive to inclination and small vibrations (Fig. 2).

Wulf approached the instrument manufacturer G\&T which had already developed the bifilar electrometer into a ready-to-use instrument - to further extend this instrument for measuring $\gamma$ rays (Fig. 3). The main improvement was that the filaments now formed the inner electrodes of the ionization chamber, which minimized the electrical capacity (Fricke, 2004).

Due to practical reasons, G\&T choose for the case a horizontal cylinder of sturdy brass. The plain sides of the cylinder were regarded as entry windows for the radiation and fabricated from thin zinc sheets. Their penetration capacity could be easily varied by adding additional sheets.

One end of the diametrically located electrometer filaments $(F)$ was fixed elastically to the inner side of the cylinder with a quartz string (Q); the other end was attached to a rod extending outwards (D). Its purpose was to enable a slight turn of the electrometer filaments in order to position them perpendicularly to the observing microscope $(\mathrm{M})$. The charge was supplied via a movable electrode $(\mathrm{S})$ that could be connected to the upper end of the filaments by means of a lever, operated from outside the case. In order to keep the inner of the cylinder dry, it was equipped with a device to enter sodium as a drying material $(\mathrm{Na})$. The filaments were illuminated through a narrow window located exactly opposite the microscope with an attached movable mirror or lamp (B) (Wulf, 1909).

\section{Victor F. Hess' investigations and further developments}

Victor F. Hess took up the idea of Bergwitz and Gockel, analysed their measurement problems and started a project with a series of manned balloon launches. The measurements were planned to be performed with a simultaneous use of several instruments of Wulf's modified $\gamma$-ray electrometers. Therefore he ordered a version of the instrument from G\&T with improved air-tightness and an even more reinforced case in order to make it weatherproof and more robust to air pressure variations. The overall design (Fig. 3) was not changed.

For the instrument manufacturers it was important to make the chamber air-tight. Necessary interfaces between parts of the case had to be tight and well-fitting. An assembling instruction for the instrument from G\&T reads:

"Die Ansätze des Gehäuses sind, um vollkommenen Luftabschluss zu erzielen, entweder durch Lötung oder Kittung, durch Lederzwischenlage oder durch Aufeinanderschleifen der Fläche abgedichtet. Kittung ist angewendet beim Beleuchtungsfenster, Lötung bei den beiden seitlichen Platten. Lederzwischenlage findet sich bei dem 


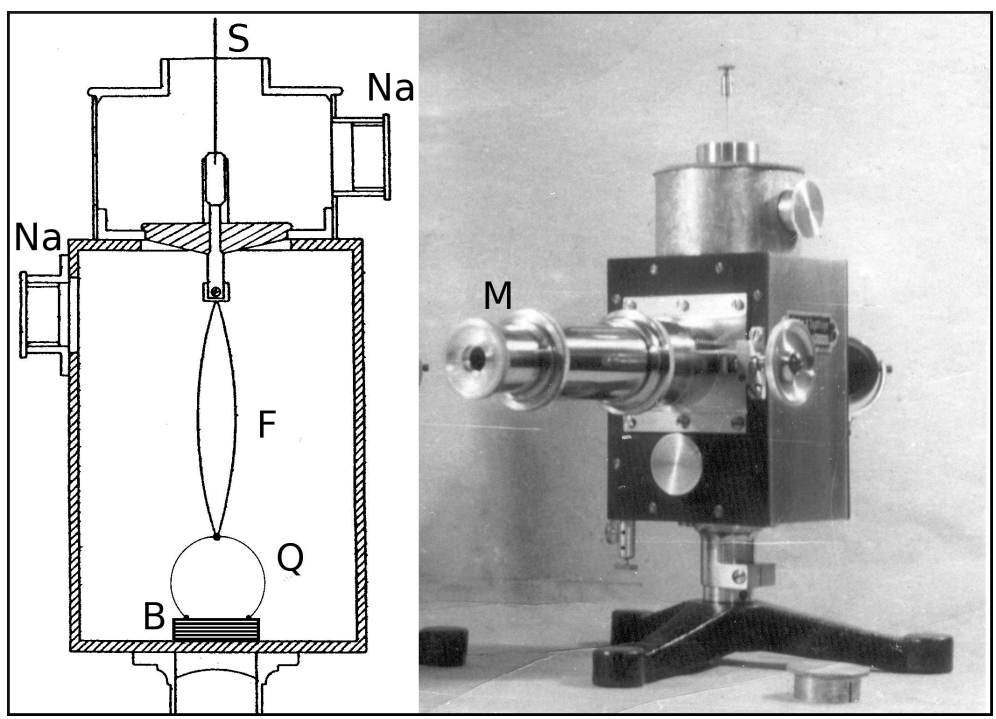

Figure 2. Wulf's bifilar electrometer (cross section, left). The lower end of metal filaments (F) was fixed to a quartz string (Q), using its elasticity as a repulsive force. The string was mounted on an amber insulator (B). The spread of the filaments was read with a microscope (M). Two openings (Na) could be connected to a sodium-drying device. The complete instrument is shown at right. Wulf received a patent on this device in 1906 (DRP 181284).

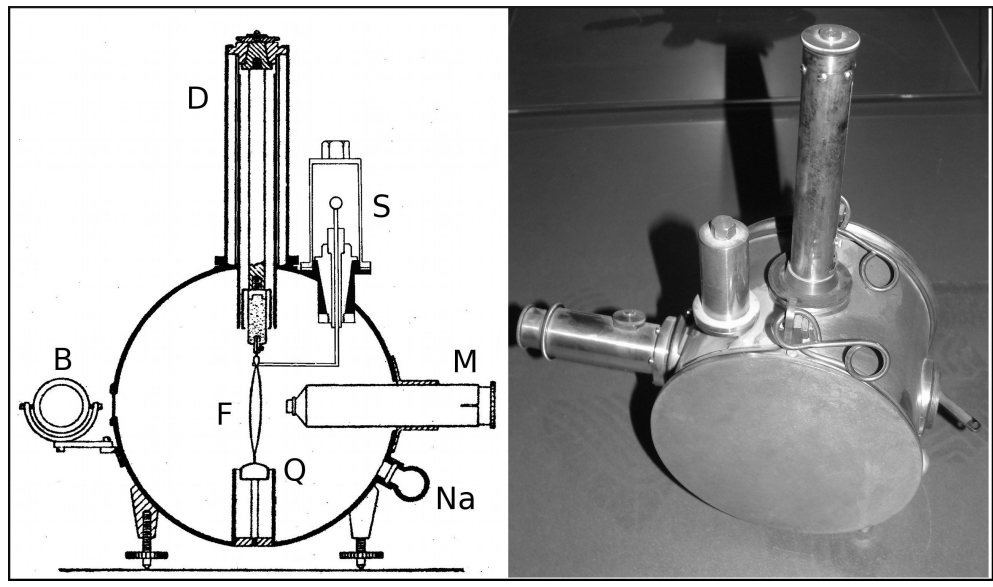

Figure 3. Wulf's $\gamma$-ray electrometer (cross section, left) and design of G\&T (right). The letters are explained in the text. The diameter of the metal case was $17 \mathrm{~cm}$, its width $13 \mathrm{~cm}$. It was this instrument that Hess used on his successful balloon flights. It is displayed in the Deutsches Museum (Munich).

Trockengefäss, Schliffflächen sind vorhanden beim Mikroskop, der Ladesonde und dem oben am Gehäuse befindlichen Schutzrohr."2

(The openings of the case are sealed to obtain complete airtightness, either by soldering, cementation, leather seals or plane-grinding. Cement is used at the observation window, soldering at the two side plates. Leather seals are applied at the drying device, grinded surfaces exist at the microscope,

${ }^{2}$ From 4 pages attached to a delivery of the instrument to Carl Dorno, Davos, without date, Archive Physical Meteorological Observatory, Davos. the charging electrode, and at the pipe on the upper side of the case).

The manufacturers in Braunschweig succeeded so perfectly that the instrument could also be used for underwater measurements (Kolhörster, 1913a).

With these instruments Hess set out for his balloon rides. After 6 flights rising only up to altitudes between $1500 \mathrm{~m}$ and $2000 \mathrm{~m}$, followed the famous seventh flight on 7 August 1912. He started in Aussig (an industrial city in Bohemia with a ready supply of hydrogen) and landed $6 \mathrm{~h}$ later in Pieskow near Bad Saarow (about $50 \mathrm{~km}$ east of Berlin) attaining a maximum altitude of $5350 \mathrm{~m}$. He used three instruments 
on this flight, two of which were supposed to detect $\gamma$ radiation (with an entrance window thickness of $3 \mathrm{~mm}$ ) and one with particular thin windows of only $0.188 \mathrm{~mm}$, supposed to identify $\beta$ radiation. Figure 4 reproduces a table of Hess' original publication that clearly shows the decrease of the ionization up to altitudes of $500 \mathrm{~m}$ to $1000 \mathrm{~m}$, and then the increase at greater heights.

Hess' interpretation was:

"Die Ergebnisse der vorliegenden Beobachtungen scheinen am ehesten durch die Annahme erklärt werden zu können, daß eine Strahlung von sehr hoher Durchdringungskraft von oben her in unsere Atmosphäre eindringt, und auch noch in deren untersten Schichten einen Teil der in geschlossenen Gefäßen beobachteten Ionisation hervorruft..."

(The results of the present observations seem to be most likely explainable with the assumption that a radiation of very strong penetration force enters our atmosphere from above and causes even in its lowest layers part of the observed ionization in closed vessels.)

More details of his measurements and results can be found in his original publication (Hess, 1912).

Soon after his successful flight Hess approached G\&T for further improvements of the Wulf-type instrument. He had realized that temperature and pressure variations introduced mechanical stress to the electrometer filaments that had to be corrected. He further found that the electrostatic field conditions within the cylinder were not optimal. According to his suggestions, G\&T developed a new $\gamma$-ray electrometer in form of a standing cylinder (Fig. 5). The electrometer filaments were made from INVAR steel (with low thermal expansion coefficient) and located in the vertical axis of the cylinder. The variation of the shielding (changed from Wulf's metal sheets) was realized by setting the whole cylinder in a wooden case that could be lined with various shielding materials (Hess, 1913).

Hess' discovery had not been fully accepted by the scientific community. One of the sceptics, the physicist Werner Kolhörster (1887-1946) launched his own balloon experiments only a few months after Hess. He already owned a version of the instrument with the improvements suggested by Hess (see above), but still regarded it as not ideally suited for further balloon measurements. He submitted the instrument back to G\&T and asked for some further changes in the construction: an improved pressure stability of the upper and lower plates of the cylinder by additional struts, and the leak-prone device to charge the electrometer to be replaced by external magnets. The latter proved to be very reliable and was used in all further instruments. In addition, the instrument was built completely from aluminium in order to save weight. Resulting from difficulties to get the aluminium case with the enclosed electrometer air tight, G\&T decided to construct the ionization chamber and the electrometer as separate units (Fig. 6).

With this instrument Kolhörster confirmed Hess' results (Kolhörster, 1913b) and became an important investigator of cosmic rays. The instrument later proved successful on a flight up to $9300 \mathrm{~m}$ in 1914 (Kolhörster, 1914) and was subsequently used for the next 6 yr (Kolhörster, 1924).

In 1924/25 Kolhörster - in collaboration with G\&T - again reconstructed his $\gamma$-ray electrometer (Fig. 7). Apart from using different materials, an important innovation was a new type of electrometer, and the filling of the cylinder with an inert gas after evacuation. This instrument was used by many observatories and research laboratories all over the world (for more details about the instrument and its usage, see Fricke, 2011).

This instrument was also used by Auguste Piccard (18841962), who reached an altitude of $15781 \mathrm{~m}$ with a balloonborne pressurized cabin in 1913, and his brother Jean Piccard (1884-1963), who measured the radiation up to $17000 \mathrm{~m}$ (Piccard, 1931).

\section{Foundation and history of "Günther and Tegetmeyer"}

Upon a call from Karl Koppe (1844-1910), Professor of Geodesy at the Technische Hochschule (Technical College) of Braunschweig (Germany), Oscar Günther (born 25 May 1863) started to work at this University in 1889 as a precision mechanic. He came from Berlin where he was an apprentice at the famous workshop for scientific instruments of Carl Bamberg (1847-1892) (e.g. Czerny, 1953). One year later Günther successfully passed his examination for the master craftsman's certificate and opened his Werkstatt für Praecisions Mechanik (workshop for precision mechanics) in Braunschweig. Soon he earned a reputation in the manufacturing of geodetic instruments, in particular with a photo theodolite (after Koppe) that earned him a silver medal at the World Exhibition in Paris in 1900.

Because of an increasing workload, he employed Otto Tegetmeyer (born 20 July 1875) in 1898. Tegetmeyer came from Leipzig, was the son of a xylograph and had already worked as a precision mechanic at the University of Rostock and at other companies.

After Tegetmeyer passed his examination for the master craftsman's certificate he and Günther signed a partnership agreement on 1 April 1901 for the enterprise Günther $\mathcal{E}$ Tegetmeyer - Werkstatt für wissenschaftliche und technische Praecisionsinstrumente (G\&T - workshop for scientific and technical precision instruments). On average, the company employed 16 mechanics in the following years (Fig. 8).

Günther had earned his reputation mainly as manufacturer of geodetic instruments where he had to face considerable competition. He maintained his hold on the market by his willingness to react to the special requests of his customers. 
Physik, Zeitschr. XIII, I912. Hess, Durchdringende Strahlung bei sieben Freiballonfahrten. I089

\begin{tabular}{c}
\hline Tabelle der Mittelwerte. \\
\hline \multirow{3}{*}{$\begin{array}{c}\text { Mittlere Höbe über } \\
\text { dem Erdboden } \\
m\end{array}$} \\
\cline { 2 - 6 }
\end{tabular}

Figure 4. Table from Hess (1912) showing the averaged measured ionization rates (ions $\mathrm{cm}^{-3} \mathrm{~s}^{-1}$ ) from the three instruments used as a function of altitude. Apparat 1 and 2 are supposed to have measured $\gamma$ radiation, Apparat 3 a possible $\beta$ radiation. In parenthesis the number of averaged samples is indicated. The accuracy of the instrument was limited by the imperfect electrical isolation between the filaments and the metal case. From Hess' instrumental details (Hess, 1912) an uncertainty of $0.3-0.5$ ions cm ${ }^{-3} \mathrm{~s}^{-1}$ can be estimated.

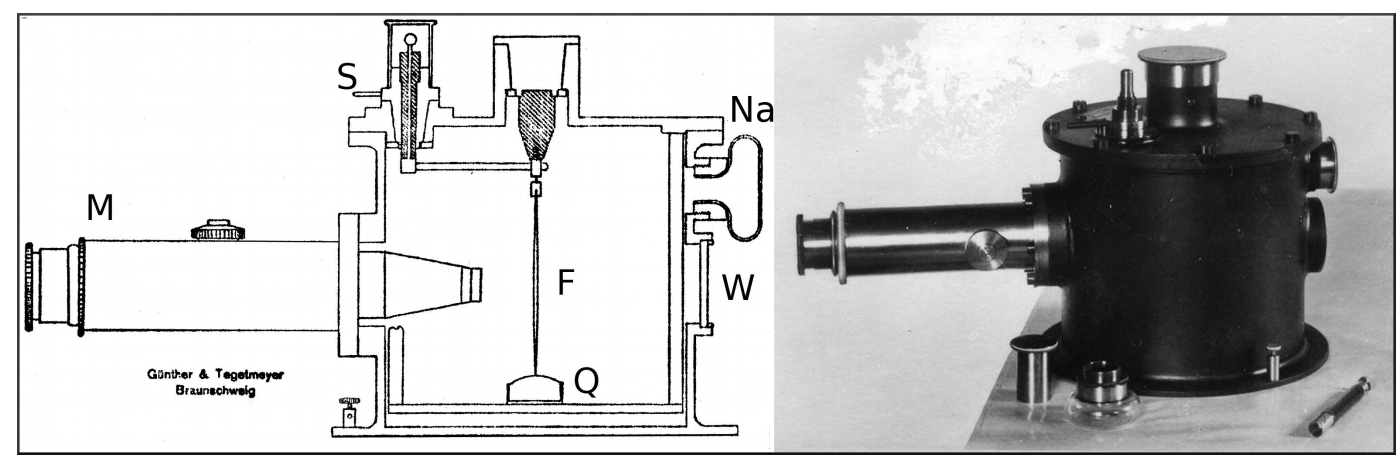

Figure 5. Wulf-type $\gamma$-ray electrometer manufactured by G\&T after Hess' suggestions. (W) is a window to illuminate the filaments (F), attached to a quartz string (Q). The filaments are observed with the microscope (M). The charge is applied through the electrode (S). A sodium container $(\mathrm{Na})$ kept the inside dry.

Around the turn of the century, the main emphasis of G\&T shifted away from geodetic instruments towards electrometers. This was a reaction to the increased research activity in atmospheric electricity and in the newly discovered radioactivity (see Introduction).

The customers of G\&T were universities, research institutes, observatories all over the world and schools. The high reputation of the manufacturer and the quality of their products led to a quick spread in the scientific community. Thereby G\&T established contacts with many well-known researchers and discoverers (see next section). The company even maintained offices outside Germany (in Italy, Argentina).

In the years following World War I, G\&T encountered economic difficulties caused by the isolation of Germany in the world, as well as inflation. As a consequence, many of the precision mechanics had to be dismissed. In addition, Günther, who was responsible for the book keeping, tried to improve the financial situation by risky transactions which failed. Günther fell ill at the beginning of 1933 and died on 26 March of that year.

In the following years, Tegetmeyer ran the manufactory as sole owner and he was able to maintain the worldwide reputation of the company until October 1944, when during World War II the premises in Braunschweig were destroyed during a bomb attack. The reconstruction after the war was difficult and Tegetmeyer felt that he could not manage it alone. So he opened G\&T for two additional partners and converted it to a limited company (GmbH in German) in 1947.

The economic difficulties for G\&T persisted, however, and therefore the shareholders agreed to an offer of the scientific instrument company Hartmann \& Braun, and G\&T became a subsidiary of this company in 1952. Only 6 yr later G\&T was deleted from the register of companies due to a restructuring of Hartmann \& Braun. The G\&T staff and their workshop became part of a newly founded company for nuclear radiation 


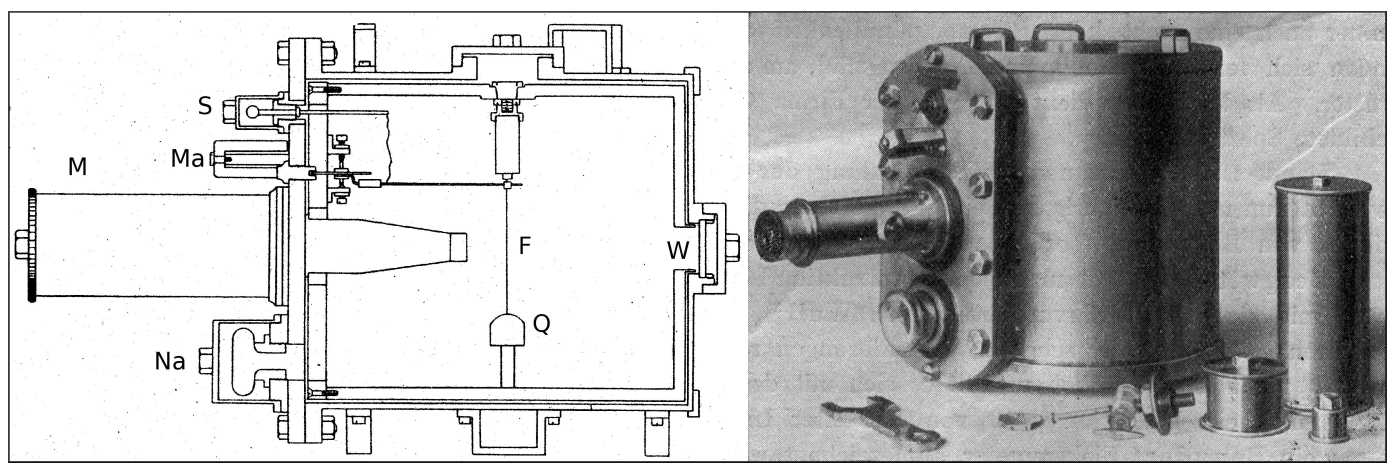

Figure 6. Further modified Wulf-type $\gamma$-ray electrometer after Kolhörster's suggestions. (Ma) is the magnet-operated device to connect the electrode (S) to the filaments (F). Other letters are the same as in Fig. 5. The operating elements could be protected with metal covers during transport, seen on the photograph at right.

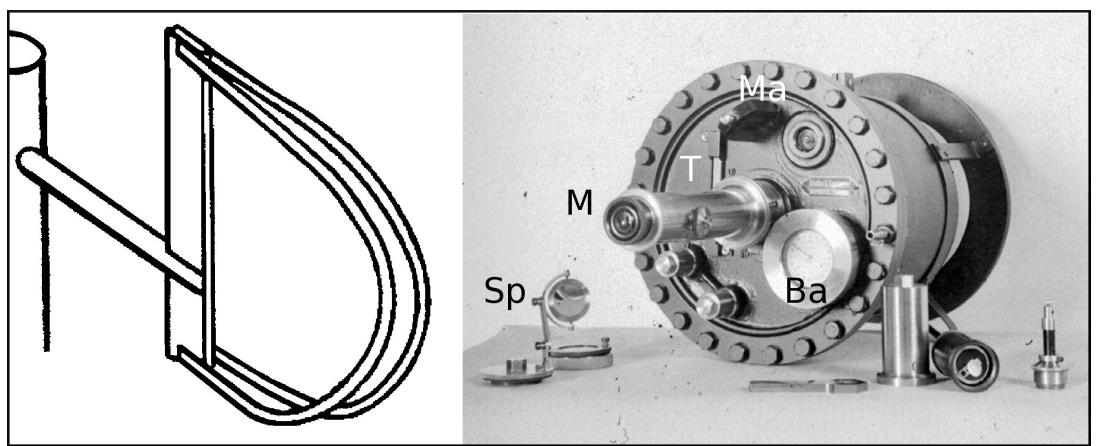

Figure 7. $\gamma$-ray electrometer after Kolhörster, manufactured by G\&T until end of the 1940s. An important innovation was the use of u-shaped filaments (left). (Ma) is the magnet-operated device to connect the electrode to the filaments, $(\mathrm{Ba})$ and $(\mathrm{T})$ are a barometer and a thermometer, respectively. The movable mirror (Sp) could be attached to a window at the rear end in order to illuminate the inside.

and nuclear reactor measuring techniques (which no longer exists) - Otto Tegetmeyer died on 21 August 1960.

A detailed publication about $G \& T$ is available in German (Fricke, 2011).

\section{Other instruments of "Günther and Tegetmeyer" and their customers}

As already mentioned, the company received its early highest reputation from the manufacturing of electro-mechanical precision instruments, like devices to investigate atmospheric electricity. Here, a collaboration with Julius Elster and Hans Geitel, teachers in Wolfenbüttel (close to Braunschweig), proved extremely fruitful. G\&T manufactured several instruments for these well-known pioneers of atmospheric electricity and radioactivity research (Fricke, 1992).

Another speciality of G\&T were mechano-optical and electro-optical devices like theodolites and photometers. The astronomer Paul Guthnick (1879-1947), the founder of photoelectric measurements of star light intensity at the Babelsberg observatory (near Berlin), developed together with G\&T a special photoelectric stellar photometer (Guthnick,
1924). Copies of these instruments can be seen in the Deutsche Museum, Munich and the Astrophysical Institute Potsdam. Admiral Umberto Nobile (1855-1978) used theodolites, photoelectric photometers and instruments for measuring atmospheric-electricity on his famous polar exhibitions 1925/26 (Nobile, 1929).

Clever marketing of their products added to G\&T's success. Oscar Günther and Otto Tegetmeyer themselves referred to contacts with well-known scientists when advertising their instruments. in addition to the above-mentioned, names like the meteorologist Karl Büttner (1903-1970), the chemists Friedrich Dolezalek (1873-1920) and Carl Engler (1842-1925), and the physicists Hans Fränz (1899-1976), Friedrich Kohlrausch (1840-1910), Heinrich Mache (18761954), Stefan Meyer (1872-1949), and Hermann Sieveking (1875-1914) are mentioned in G\&T's advertising pamphlets (Fricke, 2011).

\section{Concluding remarks}

The events and developments described in the previous chapters are a striking example of how a fruitful interplay 


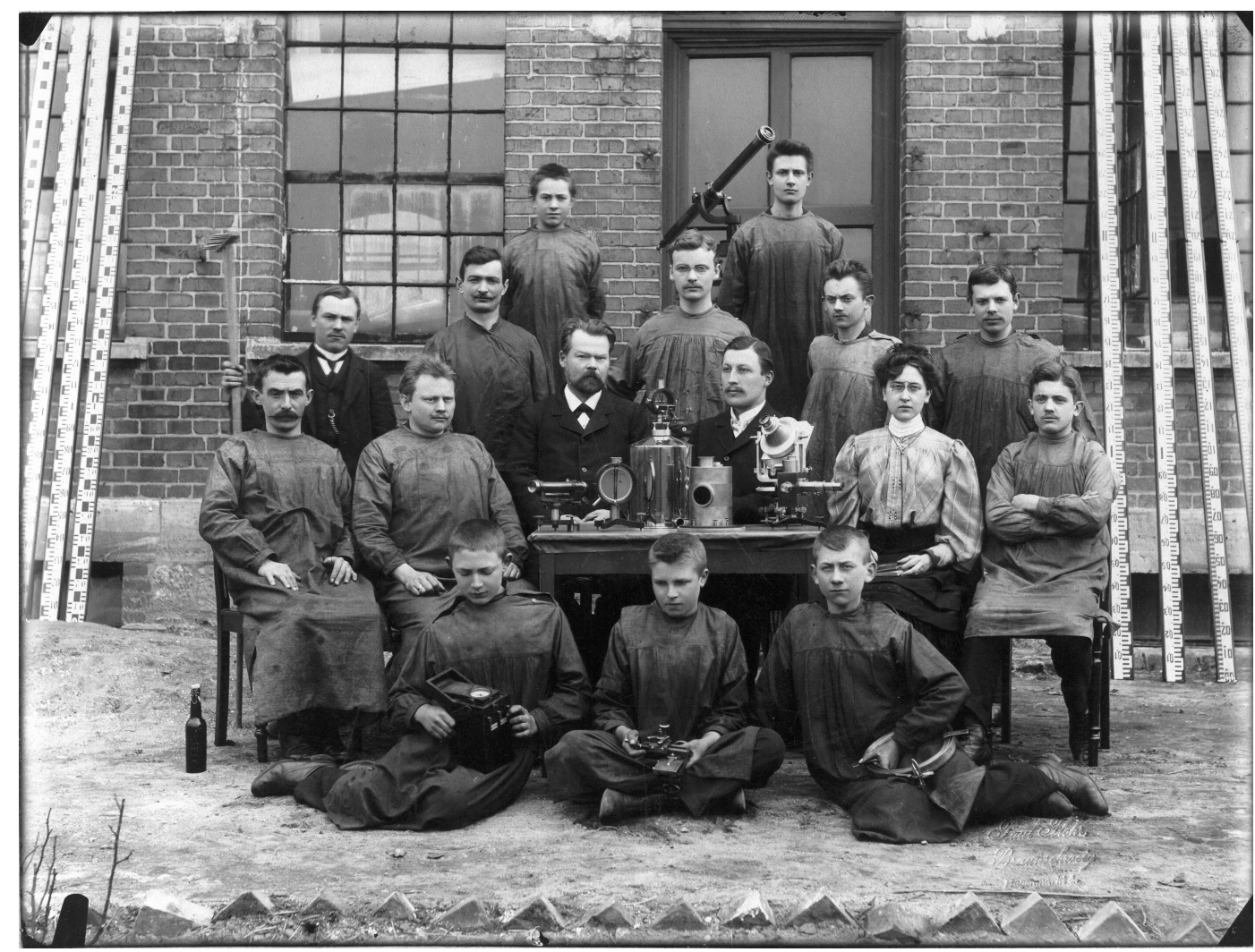

Figure 8. Oscar Günther and Otto Tegetmeyer (behind the table in the dark suits) with their staff in 1907. Displayed on the table are some instruments of their production.

between researchers and instrument builders leads to important advancements of science. Requirements and demands of scientists were optimally realized by G\&T with contemporary technology and craftsmanship. Hess' instrument was just one in a long chain of developments. The quality of the instruments and the readiness to answer customers' requests quickly spread within the scientific community. Today, masterpieces of G\&T's craftsmanship are exhibited in many museums and scientific instrument collections all over the world.

Edited by: K. Aplin

Reviewed by: A. Watson and one anonymous referee

\section{References}

Bergwitz, K.: Die $\gamma$-Strahlung des Erdkörpers und ihr Anteil an der spontanen Ionisierung der Atmosphäre; 16. Jahresbericht des Vereins für Naturwissenschaft zu Braunschweig, 196-239, 1910.

Czerny, M.: Bamberg, Johann Karl Wilhelm Anton, in: Neue Dt. Biographie. Bd. 1, 571-572, Duncker \& Humblot, Berlin, 1953.

Elster, J. und Geitel, H.: Weitere Versuche über die Elektrizitätszerstreuung in abgeschlossenen Luftmengen, Phys. Zeitschr., 2, 560-563, 1901.
Fricke, R. G. A.: J. Elster \& H. Geitel - Jugendfreunde, Gymnasiallehrer, Wissenschaftler aus Passion, Döring Druck, Braunschweig, 1992.

Fricke, R. G. A.: Günther \& Tegetmeyer - Werkstatt für wissenschaftliche Apparate, Ein Braunschweiger Unternehmen mit Weltruf, Braunschweigische Heimat, 2, 14-19, 2004.

Fricke, R. G. A.: Günther \& Tegetmeyer 1901-1958 - Instrumente für die Wissenschaft aus Braunschweig, AF-Verlag, Wolfenbüttel, 2011.

Geitel, H.: Über die Elektrizitätszerstreuung in abgeschlossenen Luftmengen, Phys. Zeitschr., 2, 116-119, 1900.

Gockel, A.: Luftelektrische Beobachtungen bei einer Ballonfahrt, Phys. Zeitschr., 11, 280-282, 1910.

Gockel, A.: Messungen der durchdringenden Strahlung bei Ballonfahrten, Phys. Zeitschr., 12, 595-597, 1911.

Guthnick, P.: Ein neues lichtelektrisches Sternphotometer, Zeitschr. für Instrumentenkunde, 24, 303-310, 1924.

Hess, V. F.: Über Beobachtungen der durchdringenden Strahlung bei sieben Freiballonfahrten, Phys. Zeitschr., 13, 1084-1091, 1912.

Hess, V. F.: Über Neuerungen und Erfahrungen zu den Radiummessungen nach der $\gamma$-Strahlenmethode, Phys. Zeitschr., 14, 11351141, 1913.

Kolhörster, W.: Über eine Neukonstruktion des Apparates zur Messung der durchdringenden Strahlung nach Wulf und die damit bisher gewonnenen Ergebnisse, Phys. Zeitschr., 14, 1066-1069, 1913a. 
Kolhörster, W.: Messungen der durchdringenden Strahlung im Freiballon in größeren Höhen, Verh. d. Dt. Phys. Gesellsch., 15, 1111-1116, 1913b.

Kolhörster, W.: Messungen der durchdringenden Strahlung bis in Höhen von 9300 m, Verh. d. Dt. Phys. Gesellsch., 16, 719-724, 1914.

Kolhörster, W.: Ein neues Fadenelektrometer, Zeitschr. für Instrumentenkunde, 24, 494-497, 1924.

Nobile, U. (Hrg.): Die Vorbereitungen und die wissenschaftlichen Ergebnisse der Polarexpedition der "Italia", J. Perthes, Gotha, 1929.
Piccard, A.: Professor Piccards Forschungsflug in die Stratosphäre, Herausgeber: Neue Augsburger Ztg., Augsburg, 1931.

Poggendorff, J. C.: Geschichte der Physik, 875 pp., Barth, Leipzig, 1879.

Wilson, C. T. R.: On the ionisation of atmospheric air, P. Roy. Soc. Lond. A, 68, 151-161, 1901.

Wulf, Th.: Über die in der Atmosphäre vorhandene Strahlung hoher Durchdringungsfähigkeit, Phys. Zeitschr., 10, 152-157, 1909.

Wulf, Th.: Beobachtungen über die Strahlen hoher Durchdringungsfähigkeit auf dem Eiffelturm, Phys. Zeitschr., 11, 811813,1910 